\title{
Floods and Hydrograms of Floods of Rivers in Arid Zones of the Mediterranean, Case of the Kingdom of Morocco
}

\author{
Boutoutaou Djamel*, Zeggane Houari, Belagoune Fares \\ Department of Applicated Science, Laboratory for the Exploitation and Development of Natural Resources in Arid Zones, \\ Ouargla University, Ouargla, Algeria \\ Email: *boutoutaoudjamel@yahoo.fr
}

How to cite this paper: Djamel, B., Houari, Z. and Fares, B. (2020) Floods and Hydrograms of Floods of Rivers in Arid Zones of the Mediterranean, Case of the Kingdom of Morocco. International Journal of Geosciences, 11, 651-666.

https://doi.org/10.4236/ijg.2020.1110033

Received: June 6, 2020

Accepted: October 27, 2020

Published: October 30, 2020

Copyright $\odot 2020$ by author(s) and Scientific Research Publishing Inc. This work is licensed under the Creative Commons Attribution International License (CC BY 4.0).

http://creativecommons.org/licenses/by/4.0/

(c) (i) Open Access

\begin{abstract}
The Moroccan territory is often exposed to brutal and destructive floods. The latter is triggered by intense rains and sudden duration (rain showers, thunderstorms). The human and material damage caused by these floods has always been very high. The violence of the flood $\left(1000 \mathrm{~m}^{3} / \mathrm{s}\right)$ of Oued Ourika on Aug 17, 1995, killed 730 people. The material damage caused by torrential rain only for the years 2008 and 2009 on the road network (roads and civil engineering works) represents more than 2.9 billion dirhams. The development of flood protection studies requires the values of the instantaneous frequency flow of a certain probability and the corresponding flood hydrogram, generally, these values are not available in the watersheds studied. The objective of this study is to propose for the Moroccan territory a method of calculating flood flows and hydrographs of floods for stream and wadis ungauged for the benefit of engineers and planners for possible studies of flood protection. The proposed method is based on the delimitation of homogeneous regions of Moroccan territory (three homogeneous regions). The frequency analysis carried out for these three zones made it possible to identify the climatic parameters necessary to calculate the flood index and consequently the frequency floods. The proposed Galton type flood hydrograph includes three parameters namely the rise time, the shape parameter and the flood index. These latter parameters are easily calculated by the formulas proposed.
\end{abstract}

\section{Keywords}

Floods, Arid, Watersheds, Basins, Hydrograph 


\section{Introduction}

The Moroccan territory is often exposed to brutal and destructive floods. Often well-defined meteorological situations lead to violent and torrential floods which are generally linked to intense, stormy and localized precipitation. Torrential mountain floods are characterized by their destructive force, they start after short bursts of showers and thunderstorms.

In Ourika, a strong thunderstorm which erupts upstream on the mountain (more than $100 \mathrm{~mm}$ in less than an hour) on Aug 17, 1995, led to a very rapid increase in flows which would have reached approximately $1000 \mathrm{~m}^{3} / \mathrm{s}$. The violence of this flood killed 730 people and the material damage was very high [1].

Following the exceptional precipitation from 20 to 30 November 2014 compared to the usual standards in the Tensift basin (136 mm in Yaacoub El Mansour, $360 \mathrm{~mm}$ in Armed, $291 \mathrm{~mm}$ in Tazitoune and $519 \mathrm{~mm}$ in Tourcht), all the rivers in the basin carried exceptional flows. The most spectacular flood flows of November 2014, recorded on Oued Tensift reached $1597 \mathrm{~m}^{3} / \mathrm{s}$ and $3500 \mathrm{~m}^{3} / \mathrm{s}$ at the stations of Abadla and Talmest respectively. Such floods have never been observed before in this region [2].

Between the years (1999-2009), Morocco experienced fifteen major floods, which left 1068 dead and affected more than 146,400 people. The damage caused by these floods was very considerable [3]. The damage caused by the torrential rains of 2008 and 2009 on the road network (roads and civil engineering works) represents more than 2.9 billion dirhams [4]. Development of flood protection projects, sizing of road crossing structures and spillways etc. is always linked to the qualitative assessment of extreme flows (floods) and their flood hydrographs.

If a long series of observation rates are available, statistical analysis allows this assessment to be made. The construction of a flood hydrogram is based on the transformation of the hyetogram of net rain into a hydrogram of direct flow. In the majority of cases, the hydro-meteorological data necessary for the statistical analysis of flood flows and the construction of their hydrographs are not available for the watershed studied. In this case, the evaluation of these characteristics is carried out using hydrological models, most often, empirical models, established on the basis of other available information (physiographic, hydrological and rainfall data) in the region or in the vicinity of the site studied. However, extrapolating these models to other regions with hydrometeorological contexts different from the one for which they were developed can lead to outliers.

The objective of this study is to propose for the Moroccan territory a method of calculating the flows of floods and hydrographs of the floods for the stream and the wadis ungauged for the benefit of engineers and planners, exercising in the hydraulics. The proposed method is based on frequency analysis and the flood index.

The regional frequency analysis method is applied for homogeneous regions [5]. The flood index is generally a stable value for each watershed (it represents the inter-annual average flood) and is easy to relate to the pluviometric and 
physical parameters of the watershed [6] [7].

The regional frequency analysis of floods allows the estimation of frequency floods from the sole knowledge of the annual maximum flood (flood index). This index can be reasonably estimated from only a few years of measurement [6] [8]. In the absence of data, the maximum annual flood can be evaluated using simple formulas including meteorological, physiographic, morphological data, etc. of the watershed [6] [7] [9].

Concerning the standardized frequency distribution curve, it is generally modeled for each of the regions by means of quantiles calculated by the laws of statistical distribution [5] [9].

\section{Material and Methods}

\subsection{Material}

The data on the flood flows and the hydrographs of the watersheds used in this study come from the database of the Agencies of the Hydraulic Basins (ABH) of Morocco. Part of the data is collected from scientific publications and state doctoral theses. The latter is used just to fill the geographic gaps by verifying each time by the method of hydrological analogy the homogeneity of these data.

The number of hydrometric stations is 50 (Table 1), they are distributed almost uni-formly over all the hydrographic basins of Morocco (Tensift, Moulouya, Sebou, Sous massa, Oum Er Rebia, Guir, Ziz Ghéris and Mediterranean coastal basins). The observation period varies from one station to another, it varies on average between 15 and 20 years (1970-2010).

\subsection{Methods}

\subsubsection{Peak Flood Flows}

In the absence of a more elaborate approach, unknown to date, allowing the estimation of flood flows, the method of regional frequency analysis is used in several countries of the world for the regionalization of flows.

\section{Delimitation of homogeneous regions on Moroccan territory}

If a group of rivers or wadis from the same region exhibits similar hydrological behavior, the region is considered to be homogeneous. In this case, it can be studied separately from the other zones [9]. From a statistical point of view, the region is said to be homogeneous, if the observations of the different sites in this region come from the same parent population [5].

Table 1. Number of watersheds according to their areas.

\begin{tabular}{ccccc}
\hline \multicolumn{5}{c}{ Area of the watershed $S\left(\mathrm{~km}^{2}\right)$} \\
\hline$<100$ & $100-1000$ & $1000-3000$ & $3000-6000$ & $>6000$ \\
\hline 3 & 18 & 11 & 10 & 8 \\
\hline
\end{tabular}


There are several methods for delimiting homogeneous regions, the most used are based on geographic criteria, physiographic and/or climatic criteria and hydrological criteria [8].

The Analysis of the relationship between the specific flow $\left(q_{0}, \mathrm{~m}^{3} / \mathrm{s} \cdot \mathrm{km}^{2}\right)$ and the area of the watershed $\left(S, \mathrm{~km}^{2}\right)$ in the different geographic regions (Central Rif, Western Rif, Eastern Rif, Middle Atlas and Saharan High Atlas) and climatic (humid zone, subhumid zone and semi-arid zone) shows a certain distribution of points around three straight lines (Figure 1), where: $P$ is average annual rainfall.

The three lines expressing the relation $q_{0}=$ fonct $(S)$ obtained make it possible to delimit three homogeneous regions for the Moroccan territory according to the annual rainfall.

\section{Regional frequency analysis}

The basic assumption of regional frequency analysis is that the region must be homogeneous. In this case, all the frequency distributions of the maximum annual floods at each of the $N$ stations $i$ are identical, to a scale factor which is the flood index. It is therefore possible to write [7]:

$$
Q_{i}=\mu_{i} K(T), i=1, \cdots, N
$$

where:

$\mu_{i}$ is a scale factor representing the average of the maximum annual floods, it is also called the flood index;

$K(T)$ is standardized regional frequency distribution.

The frequency analysis of the observation data of flood flows for each homogeneous region was developed on the basis of asymmetric hypergaussian laws (lognormal law, Gumbel law, Pearson III law, Gamma law, etc.). With the exception of a few series, all of these laws can present flood flows in Moroccan territory.

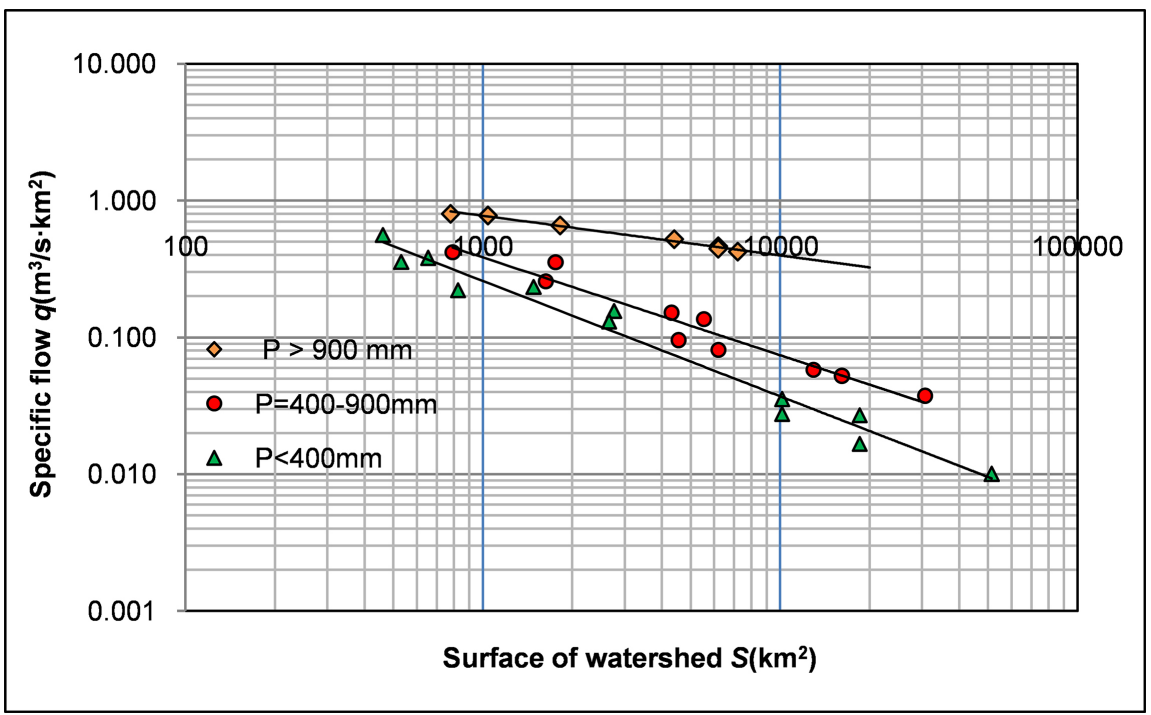

Figure 1. Relation between the specific flow $q_{0}\left(\mathrm{~m}^{3} / \mathrm{s} \cdot \mathrm{km}^{2}\right)$ and the area of the watershed $S$ $\left(\mathrm{km}^{2}\right)$ in different climatic zones. 
In very irregular regimes such as those observed in the Mediterranean region and in arid and semi-arid climates, several authors recommend calculating flood flows with low probability of occurrence by the log-normal law [10].

This law was used to calculate the quantiles of the flow rates of rivers in Moroccan territory. The normalization of flood flows was carried out using the standardized frequency distribution:

$$
K(T)=\frac{Q(T)}{Q_{0}}
$$

where:

$K(T)$ is standardized frequency distribution;

$Q(T)$ is return period flood flow $T$;

$Q_{0}$ is flood index.

The mathematical expression $K(T)=$ fonct $(T)$ for the three homogeneous regions is the same, it has the following form:

$$
K(T)=\xi \exp [\lambda \cdot \log (T)]
$$

For the three homogeneous regions, the value of the parameter $\xi$ is close to unity $(\xi \cong 1)$. The value of the parameter $\lambda$ is a function of the annual rainfall.

\section{Determination of the flood flow index}

For the Moroccan territory, R. Hazen and D. Lazarvic [6] propose a simple method to determine the flood index (maximum annual average flood $Q_{0}$ ) according to the area of the watershed $S$ and its geographic position for a slice of rain given by the following relation:

$$
Q_{0}=A(S)^{m}
$$

The formula (4) provides for two watersheds of the same size, located in the same geographic region but with different annual rainfall, the same flood index $Q_{0}$. In reality, $Q_{0}$ is different for these two basins (Table 2).

The formula of R. Hazen and D. Lazarvic for calculating the flood index $Q_{0}$ therefore requires corrections.

\subsubsection{Flood Hydrographs}

The determination of the unit hydrogram can be done directly if rain-flood pairs are known, either otherwise by empirical methods or by comparison with similar basins.

The data from the showers and their time distributions making it possible to define the unit hydrogram are not available for the case of the watersheds studied. To allow the selection of the unit hydrographs observed, we based on the following hypotheses:

Table 2. Average flood flows of river (wadi) R'dat and Oued Zat.

\begin{tabular}{cccc}
\hline River (Station) & $\begin{array}{c}\text { Area of the watershed } \\
\mathcal{S}, \mathrm{km}^{2}\end{array}$ & $\begin{array}{c}\text { Average annual } \\
\text { rainfall } P, \mathrm{~mm}\end{array}$ & $\begin{array}{c}\text { Flood index } Q_{0}, \mathrm{~m}^{3} / \mathrm{s} \\
\text { Measured }\end{array}$ \\
\hline R'Dat (Sidi Rahal) & 532 & 460 & 185 \\
Zat (Tafériet) & 528 & 521 & 125 \\
\hline
\end{tabular}


- Small watersheds of small sizes are subject to showers of constant intensity and uniformly distributed in space (unitary downpour) and sufficient to generate a unit hydrograph. For arid and semi-arid climates, the uniformity of the downpour can be perfectly obtained on these watersheds.

- Hydrographs distorted compared to the unit hydrogram generally come from localized showers. Flood hydrographs of this type will not be selected.

- Complex flood hydrographs are generally provided by generalized floods, if their flows are large it is possible to dissociate them into several unit hydrographs and therefore increase the information.

- Large watersheds are rarely fully covered by downpours. In this case, we only select flood hydrographs with low probability of occurrence (very high peak flows) which are more likely to be formed by generalized runoff over the entire watershed.

Figure 2 present an example of the unit hydrogram determination of the flood that occurred on October 23, 2010, on the Ghdat wadi (Sidi Rahal).

It is obvious that the superimposition of the reduced unit hydrographs of a catchment area, thus obtained for all floods considered unitary provides, by consideration of the median or average ordinates, a typical hydrograph which can be considered as a hydraulic characteristic of this basin. The relative values of the ordinates (in \% of the total volume of runoff) of the hydrogram distribution diagram resulting from some unitary rains at the Tahanaout station (Oued Rheraya) are given in Table 3.

From the selected unit flood flows, a typical hydrograph for each watershed was calculated based on the averages of the established standard hydrographs. This mode of representation is more direct because it avoids going through the volume. The typical hydrographs of certain rivers in Moroccan territory are illustrated in Figure 3, where: $Q_{t}$ is flood flow at time $t, Q_{p}$ is peak flood flow; $t_{m}$ is the rise time.

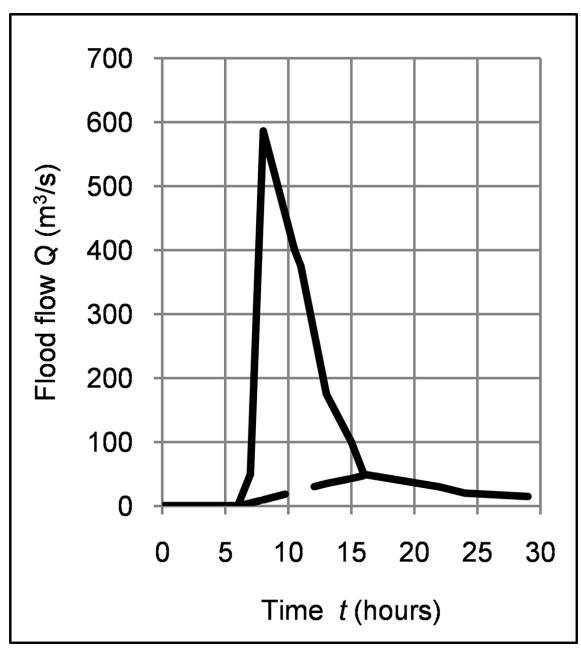

Figure 2. Dissociation of the flood hydrograph in surface and underground flow. 
Table 3. The ordinates (in \% of the total runoff volume) of the distribution diagram of the unit flood hydrographs at the Tahanaout station (Oued Rheraya).

\begin{tabular}{|c|c|c|c|c|c|c|c|c|c|c|c|c|c|c|c|}
\hline \multirow{2}{*}{$\begin{array}{c}\text { Date of flood } \\
\text { discharge }\end{array}$} & \multicolumn{15}{|c|}{ Hours } \\
\hline & 0 & 1 & 2 & 3 & 4 & 5 & 6 & 7 & 8 & 9 & 10 & 11 & 12 & 13 & 14 \\
\hline Apr. 1, 2002 & 0.0 & 0.0 & 0.0 & 5.3 & 18.6 & 20.7 & 19.1 & 13.6 & 7.4 & 5.2 & 4.1 & 2.7 & 2.1 & 1.0 & 0.0 \\
\hline Aug. 14, 2003 & 0.0 & 0.0 & 0.0 & 0.0 & 17.8 & 37.9 & 23.2 & 16.1 & 2.7 & 0.9 & 0.7 & 0.7 & 0.0 & 0.0 & 0.0 \\
\hline Aug. 17, 1995 & 0.0 & 0.0 & 0.0 & 0.0 & 0.0 & 31.8 & 27.2 & 22.9 & 10.9 & 5.4 & 0.8 & 0.5 & 0.4 & 0.0 & 0.0 \\
\hline Feb. 10, 1987 & 0.0 & 2.2 & 8.0 & 10.9 & 19.6 & 21.8 & 11.8 & 8.7 & 6.0 & 6.0 & 3.1 & 2.0 & 0.0 & 0.0 & 0.0 \\
\hline Average & 0.0 & 0.5 & 2.0 & 4.1 & 14.0 & 28.1 & 20.3 & 15.3 & 6.7 & 4.4 & 2.2 & 1.5 & 0.6 & 0.3 & 0.0 \\
\hline Median & 0.0 & 0.3 & 1.0 & 2.0 & 15.9 & 29.9 & 21.8 & 15.7 & 6.3 & 4.9 & 1.5 & 1.1 & 0.2 & 0.0 & 0.0 \\
\hline
\end{tabular}
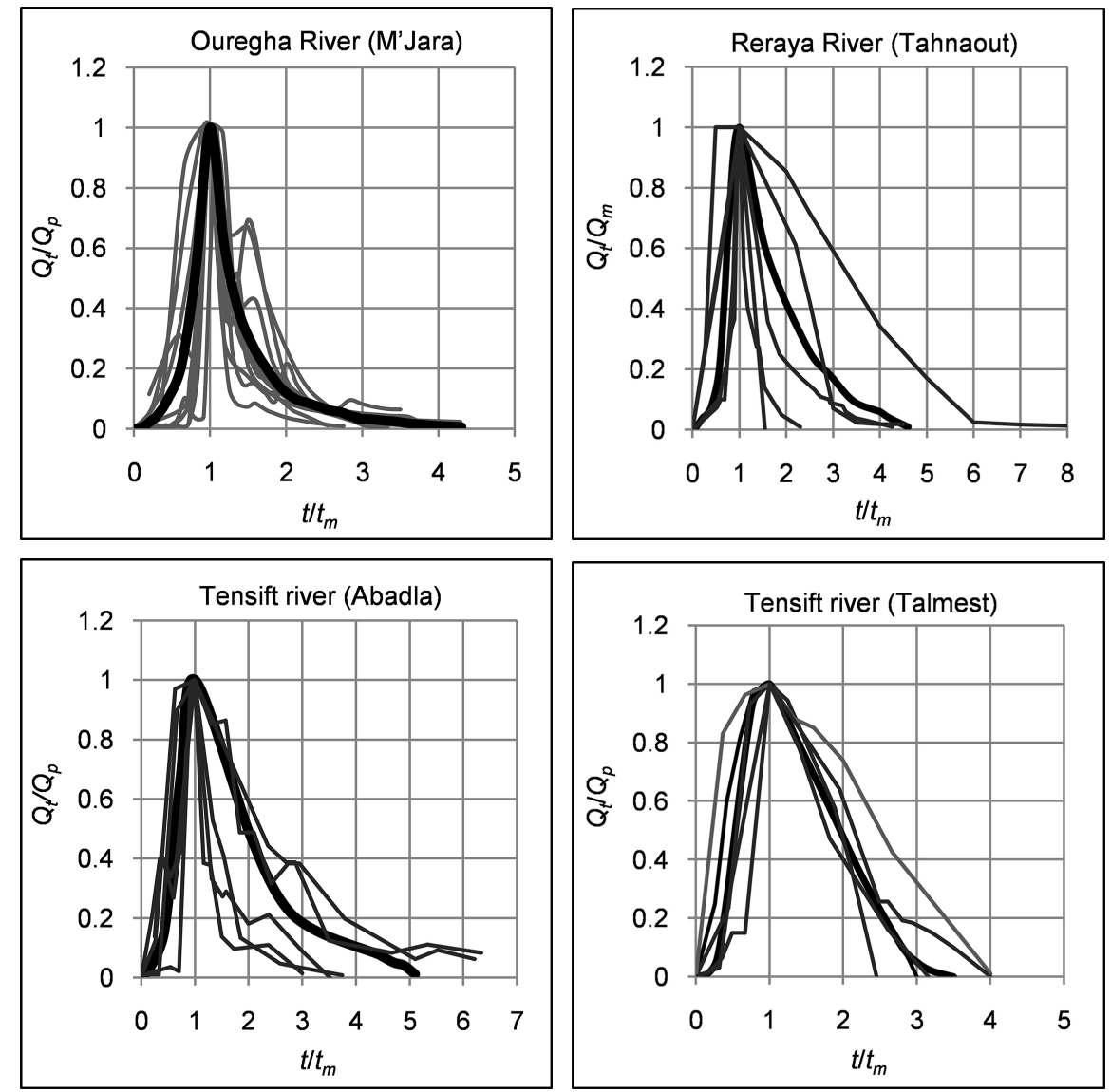

Figure 3. Hydrogrammes types de quelques cours d'eau du Maroc.

Analysis of the standard hydrograph established for each watercourse shows that the rising part of the curve is tight on the left that of the descending part and spread out to the right.

We suppose that the analytical form adopted for these standard hydrographs is that of the density function of the log-normal law (Galton law) which is chosen on the basis of the following considerations: 
1) law in the form of an asymmetrical bell, spread to the right.

2) law taking only positive values.

3) limited number of parameters constituting the law.

The density of the Galton law is presented in the following form [3]:

$$
f(x)=\left\{\begin{array}{cc}
0 & \text { pour } x \leq 0 \\
\frac{1}{x \sqrt{2 \pi} \sigma} \exp \left[-\frac{1}{2}\left(\frac{\ln x}{\sigma}\right)^{2}\right] & \text { pour } x>0
\end{array}\right.
$$

The analysis of this mathematical formulation by setting $f(x)=Q_{T}$ and $x=t / t_{m}$ shows that the closest distribution of a standard adimensional unit hydrograph or of a standard hydrogram whose volume is equal to the volume arbitrary fixed and whose shape represents on average that of all the hydrographs of runoff, is obtained almost for $\sigma=0.4$ (Figure 4).

\section{Result and Discussion}

\subsection{Peak Flows}

The analysis of the relationship between the average specific flow of the flood $q_{0}$ and the area of the watershed $S$ in the different geographical and climatic regions of the entire Moroccan territory has made it possible to delimit three homogeneous regions of genesis of the rain floods. This relationship also made it possible to define two laws for the Moroccan territory which can be expressed in the following manner:

- For the same area of the watershed, the specific flow of the annual flood $q_{0}$ increases if the climate changes from a semi-arid region to a humid region.

- For the same climatic zone, the specific flow of the average annual flood $q_{0}$ decreases with the growth of the area of the watershed.

These two laws confirm once again that the specific flood flow $q_{0}$ and therefore the flood index (maximum annual average flood flow $Q_{0}$ is a function not

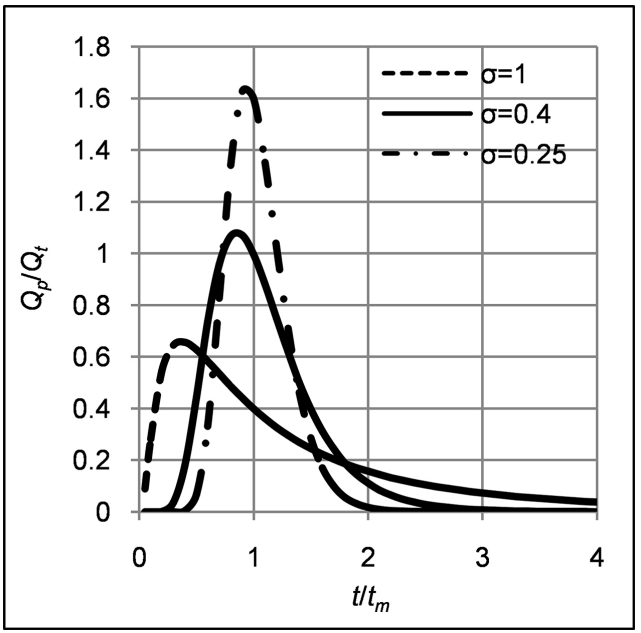

Figure 4. Distribution of the adimensional hydrograph as a function of $\sigma$. 
only of the surface of the basin but also of the pluviometry. The relationship proposed for the Moroccan territory as an alternative to that of R. Hazen and D. Lazarvic links the flood index $Q_{0}$, the area of the watershed $S$ and the average annual rainfall $P$ received by the latter, it is as follows:

$$
Q_{0}=\beta P(S)^{n}
$$

where:

$Q_{0}=$ annual average maximum flood flow $\left(\mathrm{m}^{3} / \mathrm{s}\right) ;$

$S=$ area of the watershed $\left(\mathrm{km}^{2}\right)$;

$P=$ average annual rainfall received by the watershed $(\mathrm{mm})$;

$\beta$ and $n$ are parameters, a function of the climatic zone and the average annual rainfall (Table 4).

The values of the flood index calculated by the formula (6) do not differ much from the values of the observed flood index. The correlation coefficient between the calculated and observed values is greater than 0.8 (Figure 5).

The standardized regional frequency distribution model for the three homogeneous regions of Moroccan territory is as follows:

$$
K(T)=\exp [\lambda \cdot \log (T)]
$$

The parameter $\lambda$ is tabulated according to the climatic zone and the average annual rainfall (Table 4).

\begin{tabular}{|c|c|c|c|c|c|}
\hline \multirow{2}{*}{$N^{\circ}$} & \multirow{2}{*}{ Climatic zone } & \multirow{2}{*}{$\begin{array}{l}\text { Average annual rainfall } \\
\qquad P, \mathrm{~mm}\end{array}$} & \multicolumn{3}{|c|}{ Parameters } \\
\hline & & & $\beta$ & $n$ & $\lambda$ \\
\hline I & humid & $\geq 900 \mathrm{~mm}$ & 0.0025 & 0.80 & 0.6 \\
\hline II & Subhumid & $900-400 \mathrm{~mm}$ & 0.0103 & 0.50 & 0.9 \\
\hline III & semi-arid and arid & $\leq 400 \mathrm{~mm}$ & 0.1440 & 0.25 & 1 \\
\hline
\end{tabular}

Table 4. Values of the regional parameters $\beta, n$ and $\lambda$.

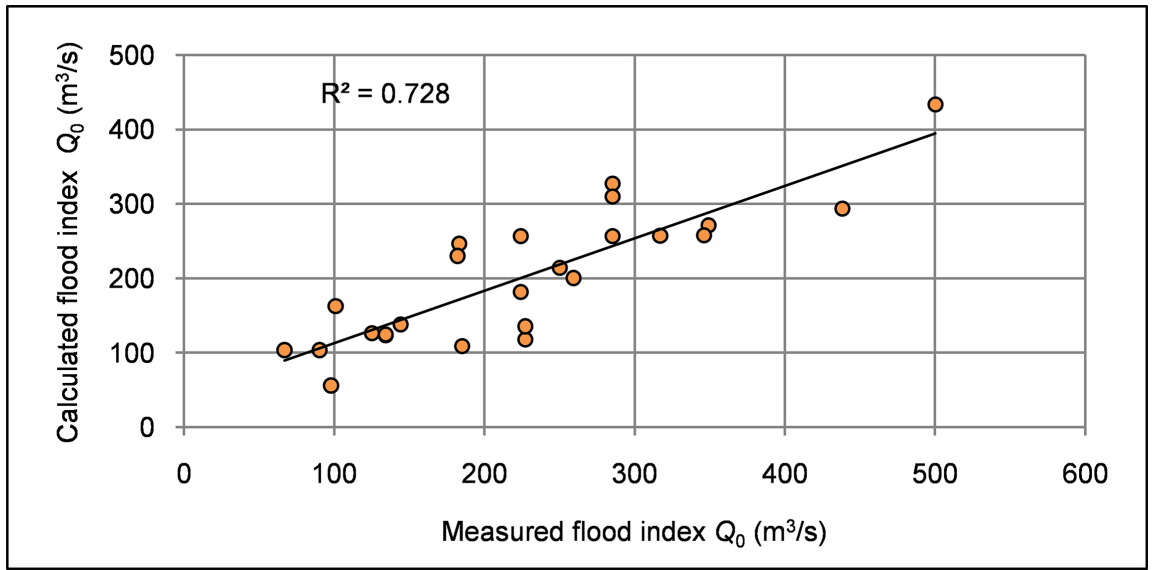

Figure 5. Comparison between the calculated and observed flood index values. 
The final regional frequency model for calculating peak flows in Moroccan territory is given by the following form:

$$
Q_{T}=Q_{0} \exp [\lambda \cdot \log (T)]
$$

or:

$$
Q_{T}=\beta P(S)^{n} \exp [\lambda \cdot \log (T)]
$$

where:

$Q_{T}=$ peak flows $\left(\mathrm{m}^{3} / \mathrm{s}\right)$, of return period $T$ (years);

$P=$ average annual rainfall received by the watershed $(\mathrm{mm})$;

$S=$ area of the watershed $\left(\mathrm{km}^{2}\right)$;

The regional parameters $\beta, n$ and $\lambda$ are tabulated according to the climatic zone and the average annual rain $P$ received by the basin (Table 4 ).

The characterization of the performance of the established regional model and the precision of the uncertainties linked to the use of the model are carried out by comparing the values of the flood flows observed and calculated by the regionalized model.

The comparison shows a good correlation between these values, it is translated by a correlation coefficient of the order of $R=0.9$.

Table 5 presents some examples of calculation of the flood flows of some rivers in the Moroccan territory.

The values of the flows calculated for wadi Ourika (Aghbalou) deviate appreciably from the values provided by the Agency of the Tensift Hydraulic Basin

\begin{tabular}{|c|c|c|c|c|c|c|c|c|c|c|c|}
\hline \multirow[t]{2}{*}{ River (Station) } & \multirow[t]{2}{*}{$\begin{array}{l}\text { Area } \\
S, \mathrm{~km}^{2}\end{array}$} & \multirow{2}{*}{$\begin{array}{l}\text { Annual } \\
\text { rain } \\
P, \mathrm{~mm}\end{array}$} & \multicolumn{3}{|c|}{$\begin{array}{l}\text { Regional parameters } \\
\qquad \text { (Table 4) }\end{array}$} & \multirow{2}{*}{$\begin{array}{c}\text { Flood flow } \\
\text { index } Q_{0}, \mathrm{~m}^{3} / \mathrm{s} \\
(6)\end{array}$} & \multicolumn{5}{|c|}{$\begin{array}{l}\text { Frequency peak flow } Q_{T}, \mathrm{~m}^{3} / \mathrm{s} \\
\frac{\text { Calculated }(8)}{\text { Observed }}\end{array}$} \\
\hline & & & $\beta$ & $n$ & $\lambda$ & & 10 & 20 & 50 & 100 & 1000 \\
\hline $\begin{array}{l}\text { Mekhazine } \\
\text { Bg. Mekh }\end{array}$ & 1820 & 1130 & 0.0025 & 0.8 & 0.6 & 1146 & $\frac{2088}{1288}$ & $\frac{2501}{2179}$ & $\frac{3175}{3156}$ & $\frac{3804}{4416}$ & $\frac{6931}{11,686}$ \\
\hline $\begin{array}{c}\text { Rheraya } \\
\text { (Tahanaout) }\end{array}$ & 225 & 670 & 0.0103 & 0.5 & 0.9 & 104 & $\frac{255}{150}$ & $\frac{334}{223}$ & $\frac{478}{345}$ & $\frac{626}{460}$ & 1540 \\
\hline $\begin{array}{c}\text { N’Fis } \\
\text { PK89/PK10 }\end{array}$ & 848 & 700 & 0.0103 & 0.5 & 0.9 & 210 & $\frac{517}{525}$ & $\frac{670}{725}$ & $\frac{969}{1000}$ & $\frac{1270}{1250}$ & 3125 \\
\hline $\begin{array}{c}\text { Ourika } \\
\text { (Aghbalou) }\end{array}$ & 503 & 600 & 0.0103 & 0.5 & 0.9 & 139 & $\frac{341}{490}$ & $\frac{447}{730}$ & $\frac{639}{1160}$ & $\frac{838}{1680}$ & 2062 \\
\hline $\begin{array}{c}\text { K'Sob } \\
\text { (Adamna) }\end{array}$ & 1480 & 330 & 0.144 & 0.25 & 1 & 295 & $\frac{802}{880}$ & $\frac{1084}{1190}$ & $\frac{1613}{1620}$ & $\frac{2180}{1940}$ & 5925 \\
\hline $\begin{array}{l}\text { Moulouya } \\
\text { Bg. Homadi }\end{array}$ & 51,500 & 200 & 0.144 & 0.25 & 1 & 434 & $\frac{1179}{1500}$ & 1594 & 2372 & $\frac{3206}{3000}$ & $\frac{8714}{7500}$ \\
\hline
\end{tabular}

Table 5. Calculation of peak flows of some wadis in Moroccan territory. 
(ABHT) [11]. The difference is certainly due to the update of the frequency study of flows by incorporating the deadly and catastrophic flood $\left(1030 \mathrm{~m}^{3} / \mathrm{s}\right)$ which was recorded on August 17, 1995, this flood does not come from the same population (natural flood flows), it is the result of an aggravated natural phenomenon (sudden rupture of the enormous temporary natural dam formed by a large stone plug upstream of the Ourika valley) [12] [13].

By the way, the hydrological characteristics of this catastrophic flood (Table 6) are very different from the characteristics of other floods recorded before and after 1995 [14].

The relative mean calculation error by the regional model (8) does not exceed $\pm 8 \%$, it can reach or sometimes exceed $\pm 30 \%$ in the semi-arid and arid zone.

Usually, the difference between the calculated and observed values increases in the following cases:

- The gradual transition from the wetland to the semi-arid and arid zone.

- The incorrect determination of the average annual rain over the entire catchment area.

\subsection{Flood Hydrographs}

The distribution of the Galton law (5) adopted as an analytical representation to derive a unit hydrograph actually has two following drawbacks:

- The peak of the flood is reached well before time $t=t_{m}$ (Figure 4).

- The shape parameter $\sigma=0.4$ is fixed (Figure 4). For other values of $\sigma$, the hydrographs will not have the meaning of a normalized dimensionless hydrograph.

To avoid these drawbacks, that is to, say fix the point in the desirable place and allow the hydrograph to marry several forms without deformation, we introduced a slight modification of the formulation of the Galton law and propose the expression (10) which will be called synthetic hydrograph type Galton:

$$
Q(t)=Q_{T}\left(\frac{t}{t_{m}}\right)^{-0.1} \exp \left[-\frac{1}{2}\left(\frac{\ln \left(\frac{t}{t_{m}}\right)}{k}\right)^{2}\right]
$$

Table 6. Characteristics of certain floods of the Ourika river at Aghbalou [14].

\begin{tabular}{cccccc}
\hline Date of flood & $\begin{array}{c}\text { Peak flow } \\
\mathrm{m}^{3} / \mathrm{s}\end{array}$ & $\begin{array}{c}\text { Volume } \\
10^{3} \mathrm{~m}^{3}\end{array}$ & $\begin{array}{c}\text { Basic time } \\
(h)\end{array}$ & $\begin{array}{c}\text { Rise time } \\
(h)\end{array}$ & $\begin{array}{c}\text { Peak } \\
\text { coefficient }\end{array}$ \\
\hline December 02, 1987 & 650 & 34.36 & 39.5 & 14 & 2.7 \\
July 14, 1989 & 823 & 34.42 & 23 & 15 & 2 \\
August 17, 1995 & 1030 & 3.6 & 4 & $0.16(\approx 10 \mathrm{~min})$ & 4.1 \\
October 28, 1999 & 762 & 25.99 & 22 & 9.5 & 2.5 \\
\hline
\end{tabular}


where:

$Q(t)=$ flood flow in $\mathrm{m}^{3} / \mathrm{s}$ at time $t$ in hours;

$Q_{T}=$ peak flow in $\mathrm{m}^{3} / \mathrm{s}$, it is determined by the formula (8);

$t_{m}=$ flood rise time in hours,

$k$ = shape parameter of the flood hydrograph;

The flood rise time $t_{m}$ is generally comparable to the concentration time $t_{c}$ for short-term showers (less than 24 hours) [15]. Which are characteristic of arid and semi-arid climates.

The concentration time for the case of the watersheds of the kingdom of Morocco can be calculated by similarity by the relationship proposed for the Algerian basins [16]. With a slight modification which takes into account the specificity of the Moroccan relief, it is of the following form:

$$
t_{c}=1.06\left(\frac{S L}{\sqrt{I}}\right)^{0.19}
$$

where:

$t_{c}=$ concentration time in hours,

$S=$ area of the watershed in $\mathrm{km}^{2}$;

$L$-length of the main river in $\mathrm{km}$;

$I$-average slope of the river in $\%$.

The relation (11) provides values of the concentration time close to those presented by the ABH (Table 7).

The shape parameter $k$ of the flood hydrograph is given by the following relation [16]:

$$
k=0.0102(S+1)^{0.4}+0.15
$$

where: $S$ is area of the watershed in $\mathrm{km}^{2}$.

Verification of the simulation quality by the proposed model was based on the comparison of the hydrographs measured with those calculated by formula (10). The relationship between the calculated and measured values is quite good and is expressed by a correlation coefficient, varying between 0.7 and 0.8 (Figure 6).

\begin{tabular}{|c|c|c|c|c|c|c|c|}
\hline \multirow[b]{2}{*}{ River } & \multirow{2}{*}{$\begin{array}{l}\text { Catchment area } \\
\qquad S, \mathrm{~km}^{2}\end{array}$} & \multirow{2}{*}{$\begin{array}{l}\text { Length of the } \\
\text { main river } \\
L, \mathrm{~km}\end{array}$} & \multicolumn{2}{|c|}{ Average slope of the river $I$} & \multicolumn{2}{|c|}{ Concentration time $t_{c}$} & \multirow[b]{2}{*}{ Reference } \\
\hline & & & $\mathrm{m} / \mathrm{m}$ & $\%$ & $\begin{array}{l}\text { Calculated by (11) } \\
\text { Hour or (Hour: min) }\end{array}$ & $\begin{array}{c}\text { Observed } \\
\text { (Hour: min) }\end{array}$ & \\
\hline RDAT & 569 & 50 & 0.032 & 3.2 & 6.7 (6 h $42 \mathrm{~min})$ & $5 \mathrm{~h} 30 \mathrm{~min}$ & \\
\hline RHERAYA & 225 & 32 & 0.072 & 7.2 & 4.8 (4 h $48 \mathrm{~min})$ & $4 \mathrm{~h} 30 \mathrm{~min}$ & \\
\hline N'FIS & 1270 & 82 & 0.025 & 2.5 & 8.7 (8 h $42 \mathrm{~min})$ & $8 \mathrm{~h} 30 \mathrm{~min}$ & {$[2]$} \\
\hline OURIKA & 503 & 45.5 & 0.069 & 6.9 & 5.9 (5 h $54 \mathrm{~min})$ & $5 \mathrm{~h} 00 \mathrm{~min}$ & \\
\hline ZAT & 528 & 55 & 0.048 & 4.8 & $6.4(6 \mathrm{~h} 24 \mathrm{~min})$ & $6 \mathrm{~h} 00 \mathrm{~min}$ & \\
\hline
\end{tabular}

Table 7. Comparison of calculated and observed concentration time values. 

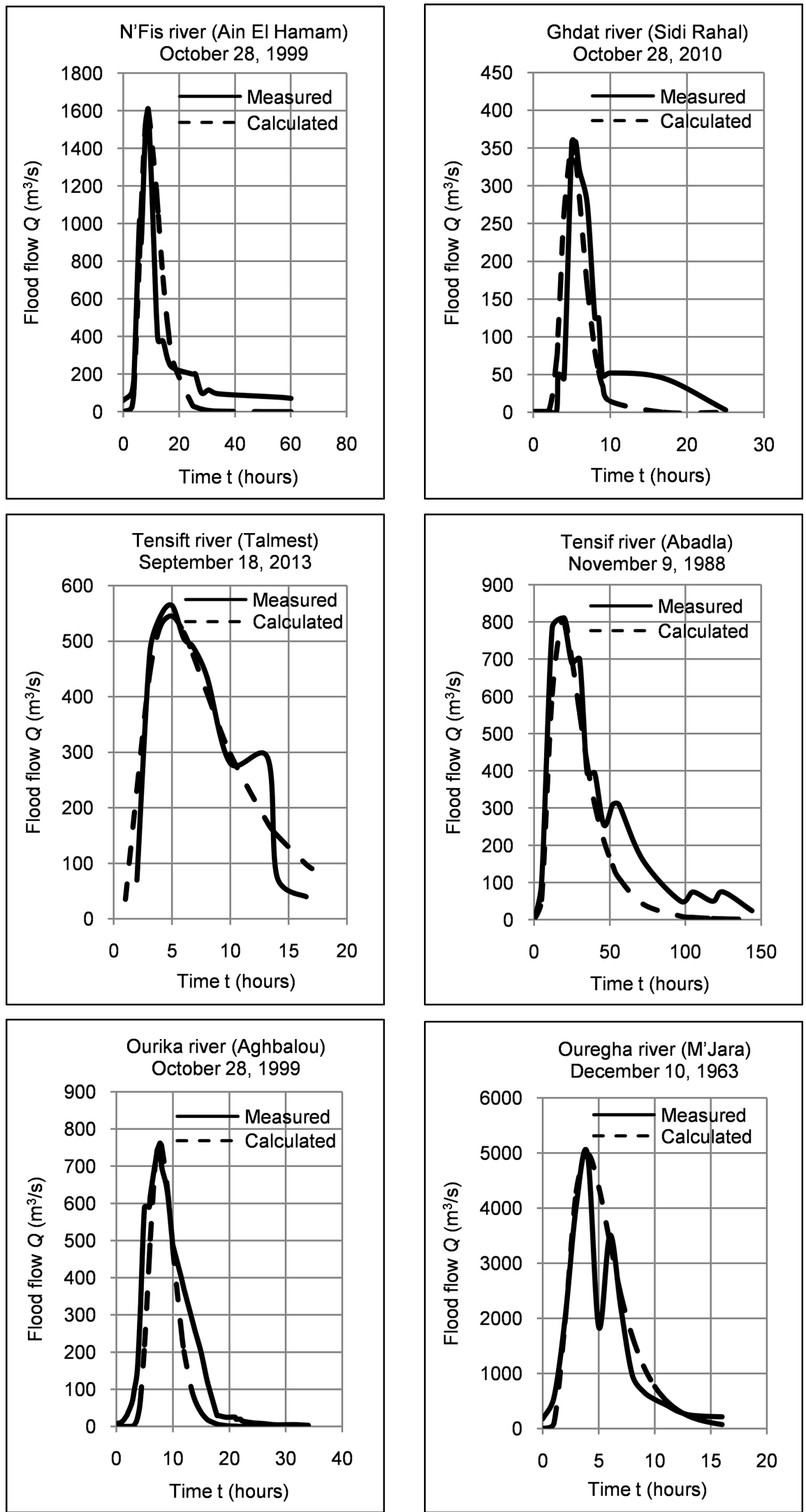

Figure 6. Comparison of the measured and calculated flood hydrographs of some Moroccan rivers. 


\section{Application}

For the study of protection of the city of Fès against floods, we propose to calculate the peak flow for $T=100$ years and its corresponding hydrograph. The basin data are: the area of the watershed, $S=879 \mathrm{~km}^{2}$; the length of the wadi $L=70$ $\mathrm{km}$; the average slope of the wadi $I=1.44 \%$. The average annual rain over the entire basin $P=550 \mathrm{~mm}$. The characteristics of the watershed are taken from reference [17].

1) The average annual flood flow (flood index) by the formula (6):

$$
Q_{0}=\beta P(S)^{n}=0.0103 \times 550 \times(879)^{0.5}=168 \mathrm{~m}^{3} / \mathrm{s}
$$

2) The peak flow of the 100-year flood by the formula (8):

$$
\begin{aligned}
Q_{100} & =Q_{0} \exp [\lambda \cdot \log (T)] \\
& =168 \exp [0.9 \log (100)]=1016 \mathrm{~m}^{3} / \mathrm{s}
\end{aligned}
$$

3) The flood hydrogram by (10):

$$
Q(t)=Q_{100}\left(\frac{t}{t_{m}}\right)^{-0.1} \exp \left[-\frac{1}{2}\left(\frac{\ln \left(\frac{t}{t_{m}}\right)}{k}\right)^{2}\right]
$$

4) The rise time $t_{m}$ by the formula (11):

$$
t_{m}=1.06\left(\frac{S L}{\sqrt{I}}\right)^{0.19}=1.06\left(\frac{879 \times 70}{\sqrt{1.44}}\right)=8.3 \text { hours }
$$

5) The form coefficient $k$ by the formula (12):

$$
\begin{aligned}
k & =0.0102(S+1)^{0.4}+0.15 \\
& =0.0102(879+1)^{0.4}+0.15=0.3
\end{aligned}
$$

6) The equation of the flood hydrograph is therefore:

$$
Q(t)=1016\left(\frac{t}{8.3}\right)^{-0.1} \exp \left[-\frac{1}{2}\left(\frac{\ln \left(\frac{t}{8.3}\right)}{0.3}\right)^{2}\right]
$$

We propose some values of the time $(t>0)$ before and after the rise time (for example $2,4,8.3,14,16,20,25$ et 30 hours) then we calculate the corresponding flow rates $\left(0.015,57,1016,211,87,13,1\right.$, et $\left.0 \mathrm{~m}^{3} / \mathrm{s}\right)$. The plot of the flood hydrogram of river Fès is presented in Figure 7.

Unfortunately, we do not have flood values measured on wadi Fès to validate the value of the 100 -year flood $\left(1016 \mathrm{~m}^{3} / \mathrm{s}\right)$ calculated. Referring to the value of the 100-year flood of the Oued N'Fis watershed at PK89/PK10 $\left(1250 \mathrm{~m}^{3} / \mathrm{s}\right)$ which is almost the same size $\left(848 \mathrm{~km}^{2}\right)$ with significantly higher rainfall $(700 \mathrm{~mm})$ (Table 5) than that of Fès and being in the same homogeneous region, the value of the flood calculated for wadi Fès can be considered reasonable. 


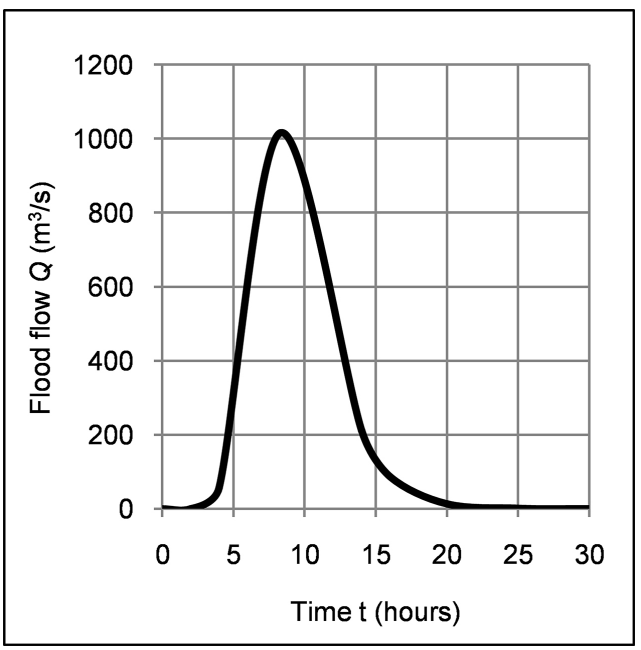

Figure 7. Hydrograph of the centennial flood $\left(Q_{100}\right)$ of river Fès (Morocco).

\section{Conclusions}

The design of flood protection works requires the knowledge of the value of the flood flow, which unfortunately often remains unknown in several regions of Moroccan territory, due to lack of measurement data and/or absence of universal methods calculation. The regionalized model for calculating the peak flow of the flood established for the Moroccan territory makes it possible to provide values characteristic of the flood regime of ungauged rivers, using only readily available characteristics, namely. the area of the watershed, the average annual rainfall received by the latter and some regional parameters, tabulated according to the average annual rainfall.

The synthetic hydrograph type Galton developed will also make it possible to derive flood hydrographs for ungauged basins throughout the Moroccan territory from the knowledge of the following hydrological characteristics: the peak flow, the surface of the basin, the length and the average slope of the river (wadi). The formulas developed above are not very precise but provide representative values for the physiographic and climatic conditions of the watersheds of the kingdom of Morocco. As data is collected, the proposed methodology can be reviewed and corrected later.

\section{Conflicts of Interest}

The authors declare no conflicts of interest regarding the publication of this paper.

\section{References}

[1] Hosking, J.R.M. and Walis, J.R. (1997) Régional Frequency Analysis: An Approach Based on L-Moments. Cambridge University Press, Cambridge, 224 p. https://doi.org/10.1017/CBO9780511529443

[2] Impact des conditions climatiques sur les infrastructures de transports. Années 
2008-2009-2010. Ministère de l'équipement et des transports 89 pages. Royaume du Maroc.

[3] Saidi, M.E., Boukrim, S., Fniguire, F. and Ramromi, A. (2012) Les écoulements superficiels sur le Haut Atlas de Marrakech. Cas des débits extrêmes. Larhyss Journal, $10,75-90$.

[4] Konstantinov, N.M., Petrov, N.A. and Vyssotski, L.I. (1987) Hydraulics, Hydrology and Hydrometry. Tom 2. Ed. Moscow Higher School. Pages: 422.

[5] Hingray, B., Picouet, C. and Musy, A. Hudrologie. 2 Une science de l'ingénieur. Presses Internationales Polytechniques, Italie, $600 \mathrm{p}$.

[6] Boutoutaou, D. and Zeggane, H. (2013) Méthode de calcul des crues des oueds de l'Algérie. 5th International Conference on Water Resources and Sustainable Development, Algiers, 24-25 Ferbruary 2013, 44-55.

[7] Clément, J.F. (2003) Les inondations dans la vallée de l'Ourika (1995-1999). Horizons Maghrébins-Le droit à la mémoire, 46, 196-200.

https://doi.org/10.3406/horma.2002.2050

[8] Etude pour la réalisation d'une cartographie et d'un système d'information géographique sur les risques majeurs au Maroc. Secrétariat d'Etat auprès du ministère de l'Energie, des Mines, de l'Eau et de l'Environnement. Version 1.0, Septembre 2008.

[9] Dubreuil, P. (1974) Initiation à l'analyse hydrologique. Masson. O.R.S.T.O.M, Paris, $216 \mathrm{p}$.

[10] Hazen, R. and Lazarvic, D. Détermination des débits maximum et des hydrogrammes de crures. Office National des Irrigations, Rabat, Maroc.

[11] Meylan, P., Favre, A.-C. and Musy, A. (2008) Hydrologie fréquentielle. Une science prédictive. Presse Polytechniques et Universitaires Romandes, Italie, 173 p.

[12] Said,i M.M., Daoudi, L., Aresmouk, M.H., Fniguire, F. and Boukrim S. (2010) The Ourika Floods (High Atlas, Morocco), Extreme Events in Semi-Arid Mountain Context. Comunicações Geológicas, 97, 113-128.

[13] (2004) Etude du plan Directeur sur le systhème de prévision et d'alerte aux crues pour la région de l'Atlas au Royaume du Maroc. Rapport définitif. Agence Japonaise de coopération internationale.

[14] Saidi, M.E.M. and Khafaoui, A. (2015) Les évènements hydrologiques exeptionnels de novembre 2014 au Maroc. L'exemple des crues du bassin versant de Tensift. Conference: Colloque Crues, gestion durable des terrs et Aménagement du territoire. Les leçons des catastrophes de l'automne 2014 dans le centre et le sud Marocians, Université Mahamed V, Rabat, 29-30 May 2015, 31-34.

[15] Anctil, F., Rousselle, J. and Lauzon, N. (2007) Hydrologie (cheminements de l'eau). Presses Internationales Polytechniques, Canada, $317 \mathrm{p}$.

[16] Reynard, E., Lasri, M., Werren, G., Obda K., Amyay M. and Taous, A. (2011) Carte des phénomènes d'inondation des bassins de Fès et Beni Mellal. Université de Lausanne et Sidi Mohamed Ben Abdellah, Lausanne, Fès.

[17] Atlas des Zones Inondables. Agence du bassin hydraulique du Tensift (ABHT), Morocco. 